\title{
Effectiveness of Mycorrhiza, Plant Growth Promoting Rhizobacteria and Inorganic Fertilizer on Chlorophyll Content in Glycine max (L.) cv. Detam-4 Prida
}

\author{
Muhammad Muhammad ${ }^{1 * *}$, Umi Isnatin ${ }^{1}$, Peeyush Soni $^{2}$, and \\ Praptiningsih Gamawati Adinurani ${ }^{3}$ \\ ${ }^{1}$ Department of Agrotechnology, University of Darussalam Gontor, J1. Raya Siman, Km 5 Siman \\ Ponorogo 63471, Indonesia \\ ${ }^{2}$ Department of Agricultural and Food Engineering Indian Institute of Technology Kharagpur, \\ 21302 Kharagpur, West Bengal, India \\ ${ }^{3}$ Department of Agrotechnology, Merdeka University of Madiun, J1. Serayu No.79, \\ Madiun 63133, East Java, Indonesia
}

\begin{abstract}
This study aimed to find an effective combination of mycorrhiza, PGPR (Plant Growth Promoting Rhizobacteria), and inorganic fertilizers. Whereas the specific purpose was observed in effective mycorrhiza to increased chlorophyll content. This study used a completely randomized design (CRD) with three factors: the $1^{\text {st }}$ factor is mycorrhiza application, the $2^{\text {nd }}$ factor is PGPR and the $3^{\text {rd }}$ factor is the application of nitrogen and phosphorus fertilizers. The data were analyzed with Analysis of Variance to determine the effect of the treatment being tried. Continued with the Least Significance Different test at a $95 \%$ confidence level. The results indicated that the most effective application in increasing total chlorophyll content was (i) the "Commercial Mycorrhiza" without being combined with PGPR and fertilizer (TP.TR.MP:80 $\mathrm{g} \mathrm{mL}^{-1}$ ). (ii) "Brawijaya Mycorrhiza" is combined with PGPR without fertilizer (TP.R.MB: $83 \mathrm{~g} \mathrm{~mL}^{-1}$ ). (iii) "Unida Mycorrhiza" without combined with PGPR and without fertilizer (TP.TR.MU: $80 \mathrm{~g} \mathrm{~mL}^{-1}$ ).
\end{abstract}

Keywords: Environmental friendly, increase soybean productivity, microbial fertilizer,

\section{Introduction}

Photosynthesis is the process by which plants harvest sunlight to produce sugars from carbon dioxide and water [1]. Photosynthesis is a metabolic process in plants to form carbohydrates that use $\mathrm{CO}_{2}$ from free air and water from the soil with the help of sunlight and chlorophyll. The process of photosynthesis will occur if there is light and an intermediate pigment, chlorophyll. Chlorophyll is a leafy or pigment green substance that has a major role in photosynthesis. The main function of photosynthesis is the formation of fat and protein energy sources from glucose. The results of the process of photosynthesis in

\footnotetext{
*Corresponding author: muhammad07@unida.gontor.ac.id
} 
the form of glucose. The chlorophyll content is a benchmark of plant growth related to crop production [2]. The higher the chlorophyll content of a plant, the higher the yield potential [3].

The main problem in increasing the production of black soybean [Glycine max (L.) Merr.] lies in the absorption of the element nitrogen, phosphorus and potassium. Not yet the maximum absorption of nutrients by black soybean plants will cause low yield production. Therefore, one alternative that can be done to increase production is to look for environmentally friendly technologies, namely using mycorrhiza and PGPR to optimize the absorption of nutrients, especially phosphorus and nitrogen [4, 5]. Mycorrhizal fungi can help plants absorb phosphorus and water absorption, while PGPR can provide nitrogen for black soybean plants. PGPR application can support the formation of mycorrhiza and can improve various functions adequately, such as Arturson's research inoculation with strains of the bacterium Paenibacillus brasilensis has been shown to increase the level of root colonization by mycorrhizal fungi and can absorb phosphorus elements so as to increase plant growth [6].

The general objective of this study is to find an effective combination of mycorrhizae, PGPR and inorganic fertilizers. While the specific purpose of this research is to find mycorrhizae that are effective in nutrient absorption to increase chlorophyll content.

\section{Methods}

Research has been carried out at the greenhouse of the Department of Agrotechnology, University of Darussalam, Gontor, Ponorogo, Indonesia. The design used was a completely randomized design (CRD) with three factors: the first factor was mycorrhizal application, the second factor was PGPR and the third factor was the application of nitrogen, phosphorus and potassium fertilizers (P). Mycorrhiza used in this study were collections from the Darussalam University - UNIDA (MU) Agrotechnology Laboratory, mycorrhiza produced by Brawijaya University $(\mathrm{MB})$ and mycorrhiza produced by the manufacturer (commercial mycorrhiza) (MP). Whereas PGPR uses the types of Pseodomonas sp. (Migula, 1894) and Bacillus Polymixa (Prazmowski, 1880, Macé 1889) from the Agrotechnology Laboratory, Darussalam University. While the black soybean [Glycine max (L.) Merr.] cv. Detam-4 Prida was obtained from BALITKABI (Balai Penelitian Tanaman Aneka Kacang dan Umbi - Indonesian Legumes and Tuber Crops Research Institute).

Stages the chlorophyll content test has been carried out as follows; leaf sampling on the $40 \mathrm{~d}$ after the application of treatment by taking samples of the leaves of the bottom, middle and top of the plant, then weighed $1 \mathrm{~g}$. Each sample was crushed with cold mortal and $1 \mathrm{~mL}$ of boric acid was added, the results of the grinding were transferred to the ependof and $4 \mathrm{~mL}$ of distilled water was added. Furthermore centrifuged at $6000 \mathrm{rad} \mathrm{s}^{-1}$ for $25 \mathrm{~mL}$. The resulting chlorophyll (pellet) extract was transferred to the reaction tube and $96 \mathrm{~mL}$ of $5 \%$ ethanol was added. Chlorophyll extracts were incubated in a dark room for $30 \mathrm{~min}$. The chlorophyll content of absorbance was measured using a spectrophotometer at wavelengths of $649 \mathrm{~nm}$ and $665 \mathrm{~nm}$.

The amount of chlorophyll-a was calculated using the Formula (1), and the amount of chlorophyll-b was calculated using the Formula (2)

$$
\begin{aligned}
& (13.7 \times \mathrm{A} 665)-(5.76 \times \mathrm{A} 649) \\
& (25.8 \times \mathrm{A} 649)-(7.60 \times \mathrm{A} 665)
\end{aligned}
$$

while the amount of chlorophyll the total is calculated using the formula chlorophyll-a plus chlorophyll-b.

The observational data were analyzed with Analysis of Variance (ANOVA) to determine the effect of the treatment being tried. If the results of the analysis have a 
significant effect then proceed with the LSD test (Least Significance Different) at a $95 \%$ confidence level [7].

\section{Results and discussions}

\subsection{Level of group dynamics}

Chlorophyll is a leafy or pigment green substance that has a major role in photosynthesis. The main function of photosynthesis is the formation of fat and protein energy sources from glucose. The results of the process of photosynthesis in the form of glucose. The process of chlorophyll synthesis through photoreduction of protochlorophyllide to chlorophyllide a and subsequently by esterification of phytol to form chlorophyll a is catalyzed by the chlorophyllase enzyme [8]. Chlorophyll content is a benchmark of plant growth related to crop production. The higher the chlorophyll content of a plant, the higher the yield potential [3].

Chlorophyll-a is the main pigment in photosynthesis which functions to electron donors in the photosynthetic electron transport chain. Chlorophyll-a most effectively absorbs the spectrum with wavelengths of $429 \mathrm{~nm}$ and $659 \mathrm{~nm}$. This chlorophyll reflects the blue-green color. Factors that influence the chlorophyll content are nutrients $\mathrm{N}, \mathrm{Mg}, \mathrm{Fe}$ and Light. All green plants contain chlorophyll-a and chlorophyll-b, chlorophyll-a making up $75 \%$ of the total chlorophyll [8]. The results showed that there were very significant differences between mycorrhizal, PGPR and fertilizer treatments according to Analysis of Variance (ANOVA) analysis.

Table 1. Clorophyll a content

\begin{tabular}{|c|c|c|c|}
\hline No. & Treatment & Average & Notation \\
\hline 1 & TP TR TM & 27 & $\mathrm{bc}$ \\
\hline 2 & TP TR MU & 29 & $\mathrm{~d}$ \\
\hline 3 & TP TR MB & 28 & $\mathrm{c}$ \\
\hline 4 & TP TR MP & 27 & $\mathrm{bc}$ \\
\hline 5 & TP R TM & 29 & $\mathrm{~d}$ \\
\hline 6 & TP R MU & 28 & $\mathrm{c}$ \\
\hline 7 & TP R MB & 28 & $\mathrm{a}$ \\
\hline 8 & TP R MP & 29 & $\mathrm{c}$ \\
\hline 9 & P TR TM & 29 & $\mathrm{~d}$ \\
\hline 10 & P TR MU & 32 & $\mathrm{~d}$ \\
\hline 11 & P TR MB & 26 & $\mathrm{e}$ \\
\hline 12 & P TR MP & 29 & $\mathrm{a}$ \\
\hline 13 & P R TM & 26 & $\mathrm{~d}$ \\
\hline 14 & P R MU & 28 & $\mathrm{c}$ \\
\hline 15 & P R MB & 28 & $\mathrm{c}$ \\
\hline 16 & P R MP & & c \\
\hline
\end{tabular}

Notes: Figures in the same column and followed by the same letter are not significantly different based on the LSD $5 \%$ further test.

The results of the analysis of chlorophyll-a absorbance value of mycorrhizal treatment without fertilizer and without PGPR were the highest "Unida Mycorrhiza" (TP.TR.MU:g $\mathrm{mL}^{-1}$ ), while the lowest treatment of mycorrhizal treatment (TP.TR.MP: $27 \mathrm{~g}$ $\left.\mathrm{mL}^{-1}\right)$. The highest mycorrhizal treatment plus PGPR without chlorophyll-a fertilizer is 
"Unida Mycorrhiza" and "Commercial Mycorrhiza" (TP.R.MU: $28 \mathrm{~g} \mathrm{~mL}^{-1}$ ), while the lowest is "Brawijaya Mycorrhiza" (TP.R.MB: $26 \mathrm{~g} \mathrm{~mL}^{-1}$ ). The treatment of mycorrhizae plus fertilizer without PGRP the highest value of chlorophyll a content is "Brawijaya Mycorrhiza" (P.TR.MB: $32 \mathrm{~g} \mathrm{~mL}^{-1}$ ), while the lowest is the "Commercial Mycorrhiza" (P.TR.MP: $26 \mathrm{~g} \mathrm{~mL}^{-1}$ ). The highest treatment of mycorrhizae plus fertilizer and PGPR chlorophyll-a content is control (P.R.TM: $29 \mathrm{~g} \mathrm{~mL}^{-1}$ ), while the lowest is "Unida Mycorrhiza" (P.R.MU: $26 \mathrm{~g} \mathrm{~mL}^{-1}$ ).

In this study, it was found that there was a different response between mycorrhizae with other mycorrhizae towards fertilizer and PGPR. The interaction of fertilizers between plants and microorganisms in accumulating and translocating metabolites between stems and roots is an indicator of the symbiotic status between plants and microorganisms. In Juge's research on soybean plants showed that inoculation of three microorganisms when applied together had a negative impact on the shoot biomass of soybeans. The association of three microorganisms will reduce the root depth for nodulation during formation and reduce the number of nodules at the end of the experiment which can show competition when the three microorganisms are applied together [9]. "Unida Mycorrhiza" in increasing chlorophyll-a content is more effectively applied alone without a mixture of fertilizer and PGPR (TP.TR.MU: $29 \mathrm{~g} \mathrm{~mL}^{-1}$ ) in Table 1. Application of "Brawijaya Mycorrhiza" more effectively combined with fertilizers without PGPR in increasing chlorophyll-a content compared to with other combinations, and get the highest value (P.TR.MB: $32 \mathrm{~g} \mathrm{~mL}^{-1}$ ). For the application of "Commercial Mycorrhiza" is more effectively combined with PGPR without fertilizer compared to other combinations and can increase the chlorophyll-a content by $28 \mathrm{~g} \mathrm{~mL}^{-1}$ (TP.R.MP).

Table 2. Clorophyll b content

\begin{tabular}{|c|c|c|c|}
\hline No & Treatment & Average & Notation \\
\hline 1 & TP TR TM & 52 & cdefg \\
\hline 2 & TP TR MU & 46 & bcde \\
\hline 3 & TP TR MB & 46 & bcd \\
\hline 4 & TP TR MP & 53 & cdefg \\
\hline 5 & TP R TM & 45 & bc \\
\hline 6 & TP R MU & 49 & bcdef \\
\hline 7 & TP R MB & 58 & g \\
\hline 8 & TP R MP & 51 & bcdefg \\
\hline 9 & P TR TM & 45 & bc \\
\hline 10 & P TR MU & 42 & b \\
\hline 11 & P TR MB & 26 & a \\
\hline 12 & P TR MP & 55 & defg \\
\hline 13 & P R TM & 44 & bc \\
\hline 14 & P R MU & 55 & defg \\
\hline 15 & P R MB & 47 & bcde \\
\hline 16 & P R MP & 47 & bcde \\
\hline
\end{tabular}

Notes : Figures in the same column and followed by the same letter are not significantly different based on the LSD $5 \%$ further test. 
Chlorophyll-b is an accessory pigment that is also responsible for the photosynthesis process. Chlorophyll has a function to collect light energy and enter chlorophyll-a during the process of photosynthesis. Chlorophyll-b is the most effective absorbing spectrum with wavelengths of $455 \mathrm{~nm}$ and $642 \mathrm{~nm}$. Chlorophyll-b reflects the yellow-green color.

The results of research on the chlorophyll-b content in Table 2 show that mycorrhizal application without fertilizer and without PGPR is ineffective. This study found a decrease in the content of chlorophyll-b when "Unida Mycorrhiza" and "Brawijaya Mycorrhiza", except the "Commercial Mycorrhiza". Applications of mycorrhizae show no significant difference from the treatment without mycorrhiza. Mycorrhizal treatment combined with PGPR without fertilizer shows that the effective application is "Brawijaya Mycorrhiza" (TP.R.MB: $58 \mathrm{~g} \mathrm{~mL}^{-1}$ ) while the lowest is the application without mycorrhiza (TP.R.TM: $45 \mathrm{~g} \mathrm{~mL}^{-1}$ ). This study found that the application of mycorrhizae combined with PGPR without fertilizer is still able to increase the chlorophyll-b content of both "Unida Mycorrhiza" or "Commercial Mycorrhiza". Mycorrhizal application treatment combined with fertilizer without PGPR shows that there is a decrease in chlorophyll-b content except the treatment of "Commercial Mycorrhiza" (P.TR.MP: $55 \mathrm{~g} \mathrm{~mL}^{-1}$ ). The most significant reduction was the treatment of "Brawijaya Mycorrhiza" (P.TR.MB: $26 \mathrm{~g} \mathrm{~mL} \mathrm{~m}^{-1}$ ). Mycorrhizal application treatment Fertilizer and PGPR showed that there was an increase in chlorophyll-b content when compared with those without mycorrhizal application, and the highest value was obtained by "Unida Mycorrhiza" treatment (P.R.MU: $55 \mathrm{~g} \mathrm{~mL}^{-1}$ ).

Table 3. Total clorophyll content

\begin{tabular}{|c|c|c|c|}
\hline No & Treatment & Average & Notation \\
\hline 1 & TP TR TM & 79 & bcde \\
\hline 2 & TP TR MU & 80 & cde \\
\hline 3 & TP TR MB & 74 & bcd \\
\hline 4 & TP TR MP & 80 & cde \\
\hline 5 & TP R TM & 73 & $\mathrm{bc}$ \\
\hline 6 & TP R MU & 78 & bcde \\
\hline 7 & TP R MB & 83 & $\mathrm{e}$ \\
\hline 8 & TP R MP & 79 & bcde \\
\hline 9 & P TR TM & 74 & $\mathrm{bc}$ \\
\hline 10 & P TR MU & 71 & b \\
\hline 11 & P TR MB & 58 & $\mathrm{a}$ \\
\hline 12 & P TR MP & 81 & cde \\
\hline 13 & P R TM & 73 & $\mathrm{bc}$ \\
\hline 14 & P R MU & 81 & cde \\
\hline 15 & P R MB & 75 & bcde \\
\hline 16 & P R MP & 75 & bcd \\
\hline
\end{tabular}

Notes : Figures in the same column and followed by the same letter are not significantly different based on the LSD $5 \%$ further test.

Chlorophyll content is a benchmark of plant growth related to crop production [1]. The results of the study of total chlorophyll content of mycorrhizal applications without fertilizer and without PGPR showed that all mycorrhizal applications can increase the total chlorophyll content of both "Unida Mycorrhiza", "Brawijaya Mycorrhiza" and "Commercial Mycorrhiza". This has also been explained by Hassani in his research 
inoculation of mycorrhizal fungi and genus Bacillus can increase chlorophyll content and $\mathrm{P}$ uptake at the initiation of tuber potato plants. Interaction between mycorrhizae and plants can increase $\mathrm{P}$ uptake and chlorophyll content by $1 \%$ compared to without mycorrhizal application [10]. The process of taking phosphate nutrients in the soil by mycorrhiza involves hyphae. Phosphorus nutrient flow in hyphae follows cytoplasmic flow, while nutrient transfer from fungi to host plants through subtle branches in host cells [11]. Increased phosphorus due to mycorrhizal inoculation in plants will affect photosynthetic activity, mycorrhizal infection in plant roots can increase nutrient translocation to the top of the plant resulting in an increase in the rate of photosynthesis and the use of assimilates in the canopy and an increase in photosynthate supply from leaves to roots. Further, phosphorus is found as phosphate in some plant minerals and is a key element of protoplasm. Phosphorus is present in water as orthophosphate [12]. Phosphate exists in three forms namely $\mathrm{H}_{2} \mathrm{PO} 4, \mathrm{HPO}_{4}{ }^{2}$, and $\mathrm{PO}_{4}{ }^{3-}$. Phosphate is generally absorbed by plants in the form of primary orthophosphate ions $\mathrm{H}_{2} \mathrm{PO}_{4}^{-}$or secondary orthophosphate $\mathrm{HPO}_{4}{ }^{2-}$ whereas $\mathrm{PO}_{4}{ }^{3-}$ is more difficult to be absorbed by plants.

The highest treatment of mycorrhizal application is unida mycorrhiza $\left(80 \mathrm{~g} \mathrm{~mL}^{-1}\right)$, while the lowest treatment value is the treatment without mycorrhiza. The treatment of mycorrhizal application combined with PGPR and without fertilizer shows that the brawijaya mycorrhiza gets the highest value (TP.R.MB: $83 \mathrm{~g} \mathrm{~mL}^{-1}$ ), while the lowest PGPR application without Mycorrhizae and without fertilizer (TP.R.TM: $73 \mathrm{~g} \mathrm{~mL}^{-1}$ ). Vafadar's research explains that using mycorrhizae and PGPR can significantly increase leaf dry mass production and stevioside concentration. The application of double inoculation of mycorrhizal fungi and N-binding bacteria is most effective for increasing plant growth, plant nutrient uptake, total chlorophyll content and stevioside content [13]. Mycorrhizal application treatment combined with fertilizer without PGPR shows that mycorrhizal application has decreased total chlorophyll content except the application of mycorrhizal (P.TR.MP: $81 \mathrm{~g} \mathrm{~mL}^{-1}$ ), while the lowest mycorrhizal treatment is "Brawijaya Mycorrhiza" (P.TR.MB: $58 \mathrm{~g} \mathrm{~mL}^{-1}$ ).

Mycorrhizal application treatment combined with PGPR and fertilizer shows that all mycorrhizal applications experience an increase in total chlorophyll content, the highest mycorrhizal application is "Unida Mycorrhiza" (PRMU: $81 \mathrm{~g} \mathrm{~mL}^{-1}$ ), while the lowest mycorrhizal application is PGPR application and fertilizer without mycorrhizae (PRTM: $\left.73 \mathrm{~g} \mathrm{~mL}^{-1}\right)$. This study found that the most effective application of mycorrhizae in increasing total chlorophyll content was "Commercial Mycorrhiza" without combined with PGPR and fertilizer (TP.TR.MP: $80 \mathrm{~g} \mathrm{~mL}^{-1}$ ) because if combined with PGPR and fertilizer it would decrease the total chlorophyll content ( PRMP: $75 \mathrm{~g} \mathrm{~mL}^{-1}$ ). The most effective application of "Brawijaya Mycorrhiza" in increasing total chlorophyll content is "Brawijaya Mycorrhiza" combined with PGPR without fertilizer (TP.R.MB: $83 \mathrm{~g} \mathrm{~mL}^{-1}$ ), if the application of "Brawijaya Mycorrhizae" combined with fertilizer will dramatically decrease the total chlorophyll content (P .TR.MB: $58 \mathrm{~g} \mathrm{~mL}^{-1}$ ). The most effective application of "Unida Mycorrhiza" in increasing total chlorophyll content is "Unida mycorrhiza" without combined with PGPR and without fertilizer (TP.TR.MU: $80 \mathrm{~g} \mathrm{~mL}^{-1}$ ), if unida mycorrhiza is combined with PGPR and fertilizer can still increase the total chlorophyll content ( PRMU: $81 \mathrm{~g} \mathrm{~mL}^{-1}$ ) and if "Unida Mycorrhiza" is combined with fertilizer without PGPR, it will decrease the total chlorophyll content (P.TR.MU: $\left.71 \mathrm{~g} \mathrm{~mL}^{-1}\right)$.

\section{Conclusion}

The most effective application in increasing total chlorophyll content was (i) the "commercial mycorrhiza" without being combined with PGPR and fertilizer (TP.TR.MP: 
$80 \mathrm{~g} \mathrm{~mL}^{-1}$ ). (ii) "Brawijaya mycorrhiza" is combined with PGPR without fertilizer (TP.R.MB: $83 \mathrm{~g} \mathrm{~mL}^{-1}$ ). (iii) "Unida mycorrhiza" without combined with PGPR and without fertilizer (TP.TR.MU: $80 \mathrm{~g} \mathrm{~mL}^{-1}$ ).

Gratitude is devoted to the Ministry of Research and Technology and Higher Education of Republic of Indonesia, for funding this research by Beginner Lecturer Research Program with decision letter No. 113/SP2H/LT/DRPM/2019. Gratitude is also directed to Directorate of Research and Community Service, University of Darussalam Gontor, for the opportunity to carry out this research.

\section{References}

1. L. Guanter, Y. Zhang, M. Jung, J. Joiner, M. Voigt, J.A. Berry, et al. Proceedings of the National Academy of Sciences, 111,14:E1327-E1333(2014).

https://www.pnas.org/content/pnas/111/14/E1327.full.pdf

2. E. Proklamasiningsih, I.D. Priyambodo, D. Rachmawati, R.P. Sancayaningsih, Bionatura Jurnal Ilmu-ilmu Hayati dan Fisik, 14,2:107-114(2012). [in Bahasa Indonesia] https://repository.ugm.ac.id/101262/

3. E.D. Purbajanti, F. Kusmiyati, W. Slamet, P.G. Adinurani,. AIP Conference Proceedings. 1755,130013:1-4 (2016); https://doi.org/10.1063/1.4958557

4. P.G. Adinurani, S. Rahayu, L. S. Budi, A. Nindita, P. Soni, M. Mel,. MATEC Web Conference. 164, 01035: 1-5(2018). https://doi.org/10.1051/matecconf/201816401035

5. P.G. Adinurani, S. Rahayu, L. S. Budi, S. Pambudi, P. Soni, IOP Conference Series: Earth and Environmental Science 293,012032:1-7(2019). doi:10.1088/1755$\underline{1315 / 293 / 1 / 012032}$

6. S.M. Nadeem, M. Ahmad, Z.A. Zahir, A. Javaid, M. Ashraf, Biotechnol. Adv. 32,2:429-448(2014). https://www.sciencedirect.com/science/article/abs/pii/S073497501300222X

7. L.J. Williams, H. Abdi, Encyclopedia of research design. 218:840-853(2010). http://dx.doi.org/10.4135/9781412961288.n154

8. A.J. Pratama, Analisis Kandungan Klorofil Gandasuli (Hedychium gardnerianum Shephard ex Ker-Gawl) pada Tiga Daerah Perkembangan Daun yang Berbeda [Gandasuli Chlorophyll Content (Hedychium gardnerianum Shephard ex Ker-Gawl) in Three Different Leaf Development Areas]. Seminar Nasional Konservasi dan Pemanfaatan Sumber Daya Alam 2015. Sebelas Maret University, Solo.(2015).p.216219. [in Bahasa Indonesia]. https://core.ac.uk/download/pdf/289792435.pdf

9. C. Juge, D. Prévost, A. Bertrand, M. Bipfubusa, F.P. Chalifour, Appl. Soil Ecol. 61,147-157(2012).

https://www.researchgate.net/profile/Christine_Juge2/publication/257382118_Growth _and_biochemical_responses_of_soybean_to_double_and_triple_microbial_associatio ns_with_Bradyrhizobium_Azospirillum_and_arbuscular_mycorrhizae/links/59e4f3a5 458515250246ec50/Growth-and-biochemical-responses-of-soybean-to-double-andtriple-microbial-associations-with-Bradyrhizobium-Azospirillum-and-arbuscularmycorrhizae.pdf

10. F. Hassani, M. Ardakani, A. Asgharzade, F. Paknezhad, A. Hamidi, Int. J. Biosci. 4,1:244-251(2014).

http://citeseerx.ist.psu.edu/viewdoc/download?doi=10.1.1.651.8551\&rep=rep1\&type= $\underline{\mathrm{pdf}}$

11. M. Muhammad, H. Setyaningrum, Jurnal Agroqua: Media Informasi Agronomi dan Budidaya Perairan, 15,2:1-12(2017). https://journals.unihaz.ac.id/index.php/agroqua/article/view/94 
12. M. Muhammad, U. Wasit, Kajian Kesuburan Tanah di Kabupaten Madiun [Soil Fertility Study in Madiun Regency], Seminar Nasional Dalam Rangka Dies Natalis UNS Ke 43 Tahun 2019. (2019).p. 42-53. [in Bahasa Indonesia] https://core.ac.uk/reader/295746928

13. F. Vafadar, R. Amooaghaie, M. Otroshy, J. Plant Interac. 9,1:128-136(2014). https://www.tandfonline.com/doi/pdf/10.1080/17429145.2013.779035 